\title{
KAJIAN KESIAPAN IMPLEMENTASI BISNIS CONTINUITY MANAGEMENT SYSTEM (BCMS) BERBASIS ISO 22301 (STUDI KASUS: PT XYZ)
}

\author{
Whildan Zainudin ${ }^{1)}$ dan Febriliyan Samopa ${ }^{2)}$ \\ Program Studi Magister Manajemen Teknologi, Institut Teknologi Sepuluh Nopember ${ }^{1)}$ \\ Jl. Cokroaminoto 12A, Surabaya, 60264, Indonesia \\ Jurusan Teknik Informatika, Institut Teknologi Sepuluh Nopember ${ }^{2)}$ \\ Jl. Raya ITS, Keputih, Sukolilo, Surabaya, 60111, Indonesia \\ email:wzainudi@gmail.com ${ }^{1)}$,samopa@gmail.com ${ }^{2)}$
}

\begin{abstract}
ABSTRAK
Seiring dengan makin berkembang dan semakin matang kondisi industri IT di tanah air maka saat ini mulai muncul tuntutan dari calon pengguna jasa atau pengguna eksisting kepada PT XYZ mengenai keharusan memiliki Bussniess Continuity Management System (BCMS) dalam penyediaan layanannya. Hal tersebut yang melatar belakangi management PT XYZ untuk melakukan implementasi BCMS. Adapun tujuan dari implementasi ini adalah menghasilkan pemetaan kondisi as-is terhadap ISO 22301, menentukan tingkat kesiapan PT XYZ dalam implementasi ISO 22301, mendapatkan strategi pemenuhan gap dan memiliki panduan atau prosedur operational baku (POB) mengenai BCMS. Penelitian ini diawali dengan studi literatur, kemudian pemetaan kondisi as-is dilakukan dengan melakukan review dokumen, wawancara dan observasi. Dalam penelitian ini keabsahan data dilakukan dengan teknik triangulasi untuk mendapatkan kesimpulan kesiapan. Kemudian dilakukan analisa gap dan ditentukan strategi pemenuhan gap. Hasil penelitian ini dari cheklist assessmen 106 kontrol 39,6\% kontrol comply, 46.2\% comply dengan catatan dan 14.1\% belum comply. Didukung dengan pernyataan top managemen. Bahwa PT XYZ siap implementasi ISO 22301 dengan catatan dapat melakukan perbaikan-perbaikan proses, implementasi dan dokumentasi.
\end{abstract}

Kata Kunci: Kesiapan, BCMS, ISO 22301, Triangulasi

\section{PENDAHULUAN}

Pada era saat ini bisnis sangat rentan terhadap gangguan. Hal ini hampir mustahil untuk memprediksi gangguan dari waktu dan cakupan dampaknya. Oleh karena itu organisasi perlu melakukan pendekatan proactive dilengkapi dengan kerangka pendukung keputusan untuk melindungi diri terhadap gangguan [1]

PT XYZ memerlukan strategi dalam melanjutkan bisnisnya yaitu memastikan ketersediaan berbagai solusi layanan IT kepada pelanggannya. Seiring dengan makin berkembang dan semakin matang kondisi industri IT di tanah air maka saat ini mulai muncul tuntutan dari calon pengguna jasa atau pengguna eksisting kepada PT XYZ mengenai keharusan memiliki Bussniess Continuity Management System (BCMS) dalam penyediaan layanannya. Hal tersebut yang melatar belakangi manajemen PT XYZ untuk memiliki panduan atau prosedur operational baku (POB) mengenai BCMS sehingga dapat menjalankan proses bisnis pada kondisi tidak biasa. Pedoman atau panduan ini akan sangat bermanfaat bagi bisnis PT XYZ, karena selain berfungsi sebagai pedoman kerja di saat terjadi kondisi tidak biasa, dokumen ini juga dapat digunakan sebagai jaminan kepada pengguna jasa atau calon pengguna jasa bahwa PT $\mathrm{XYZ}$ dapat menjamin kelangsungan proses bisnis mereka di saat terjadi kondisi tidak biasa.

Dalam membangun panduan operasional baku, PT XYZ mengacu pada ISO 22301:2012
Business Continuity Management dengan alasan agar bisa mendapat sertifikasi ISO yang berdampak pada reputasi PT XYZ sebagai penyedia jasa. Dalam pelaksanaannya akan dilakukan penilaian kesesuaian kondisi dan situasi aktual perusahaan saat ini dengan persyaratan standar ISO 22301:2012, agar dapat diukur sejauh mana atau seberapa besar kesenjangan terhadap standar ISO 22301:2012. Dari kesenjangan (gap) tersebut dibuatkan solusi sehingga sesuai dengan persyaratan dari ISO 22301:2012.

Sepanjang pengetahuan peneliti, belum ada penelitian yang judulnya sama persis dengan penelitian ini. Sebagai permasalahan yaitu pertama, memetakan kondisi PT XYZ saat ini dalam kaitan implementasi Business Continuity Management (BCMS) berdasarkan ISO 22301:2012. Kedua, bagaimana menentukan tingkat kesiapan PT XYZ untuk implementasi BCMS yang mengacu pada ISO 22301:2012. Ketiga, bagaimana menemukan strategi yang dapat diusulkan untuk melengkapi kesenjangan (gap) antara kondisi sebelum dan persyaratan implementasi BCMS? Keempat, bagaimana menyusun prosedur operasional baku yang sesuai dengan persyaratan implementasi BCMS?

Tujuan penelitian adalah pertama menghasilkan pemetaan kondisi saat ini (as-is) di PT XYZ terhadap klausul ISO 22301. Kedua, menentukan tingkat kesiapan PT XYZ dalam mengimplementasikan ISO 22301. Ketiga, 
menetukan strategi pemenuhan gap untuk dapat mengimplementasikan ISO 22301. Keempat, untuk menghasilkan prosedur operasional baku (POB) untuk implementasi BCMS sesuai ISO 22301:2012.

Manfaat penelitian ini dapat dibedakan secara internal (Perusahaan) yaitu Memberikan panduan secara lengkap untuk menghadapi situasi yang tidak biasa sehingga dapat mengatasi masalah dengan prosedur yang benar, menambah competitive advantages kepada customer berupa confidentiality data untuk keberlangsungan bisnis, sedangkan secara eksternal (Customer) yaitu meningkatkan value dari bisnis yang dimiliki customer berupa reputasi yang meningkat karena bisnis yang dijalankan sudah mempunyai standard ISO 22301:2012.

\section{TINJAUAN PUSTAKA}

Dalam penelitian ini tinjauan pustaka mebahas mengenai studi literatur ISO 22301, prosess bisnis PT XYZ dan teori triangulasi.

\section{A. ISO 22301:2011 (BCMS)}

ISO 22301 merupakan persyaratan untuk merencanakan, menetapkan, menerapkan, mengoperasikan, memantau, mereview, mempertahankan dan terus meningkatkan sistem manajemen yang terdokumentasi untuk mempersiapkan, menanggapi dan memulihkan diri dari kejadian yang mengganggu (disruptive) ketika gangguan itu terjadi [2]. Persyaratan yang ditentukan dalam ISO 22301 generik dan dimaksudkan untuk dapat diterapkan pada semua organisasi, terlepas dari jenis, ukuran dan sifat organisasi. Tingkat penerapan persyaratan ini tergantung pada lingkungan operasi organisasi dan kompleksitasnya.

ISO 22301:2012 terdiri dari 10 klausul, tetapi klausul yang harus dilaksanakan mulai dari klausul 4 sampai 10 [3] yaitu:

- Clause 4: Kontek organisasi (Context of the organization);

- Clause 5: Kepemimpinan (Leadership);

- Clause 6: Perencanaan (Planning);

- Clause 7: Dukungan (Support);

- Clause 8: Operasional (Operation);

- Clause 9: Evaluasi kinerja (Performance evaluation);

- Clause 10: Perbaikan berkelanjutan (Improvement).

Dalam kaitan dengan model PDCA, maka: Plan, terdiri dari Clause 4, Clause 5, Clause 6, dan Clause 7, Do, terdiri dari Clause 8, Check, terdiri dari Clause 9, Act, terdiri dari Clause 10

Standar ISO merupakan sertifikasi ditingkat korporasi atau perusahaan, sehingga persyaratan yang ISO yang telah dibakukan mudah untuk diadopsi dengan kebijakan diperusahaan. Gambar 1 menggambarkan keselasaran dari lingkup BCMS, dengan mempertimbangkan tujuan strategis organisasi, produk dan layanan, toleransi risiko, peraturan, kontrak dan mendukung keselarasan dengan para pihak pemangku kepentingan [4].

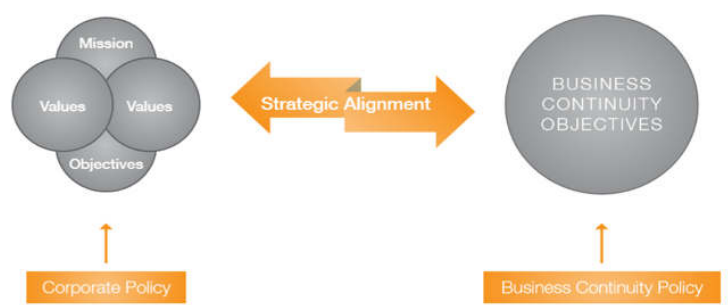

Gambar 1. Hubungan antara kebijakan korporate dengan BCMS [5].

ISO 22301 dapat dengan mudah dihubungkan dengan standar Business Continuity dan Keamanan Informasi yang lain (ISO 9001,ISO 27001) [5]. Semakin banyak sistem manajemen yang diterapkan, semakin banyak manfaat yang akan diperoleh bisnis.

\section{B. Proses Bisnis PT XYZ}

PT XYZ merupakan salah satu perusahaan solusi IT terkemuka dengan pengalaman lebih dari 25 tahun di Indonesia, saat ini PT XYZ memiliki lebih dari 1000 karyawan yang berpengalaman dan memiliki sertifikasi profesional di bidang IT. Dengan pengalaman dan kompetensi yang dimiliki, PT XYZ melakukan inovasi dalam memberikan solusi layanan IT yang meliputi jasa konsultasi, managed IT services, layanan software development, dan data center operations bagi perbankan (konvensional dan syariah), perusahaan keuangan, telekomunikasi, manufaktur, distribusi dan sektor lainnya.

Secara garis besar aktifitas bisnis PT XYZ adalah memberikan layanan data center dan fasilitas pendukungnya, baik perangkat keras maupun perangkat lunak. Layanan maintenance dan monitoring perangkat dan operasional di data center kepada customer untuk jangka waktu tertentu seperti yang telah disepakati bersama dan dituangkan ke dalam sebuah dokumen kontrak.

\section{Triangulasi}

Dalam penelitian ini keabsahan data dilakukan dengan teknik triangulasi. Triangulasi adalah aplikasi studi yang menggunakan multi metode untuk menelaah fenomena yang sama [6]. Metode triangulasi paling umum dipakai dalam uji validitas dalam penelitian kualitatif [7]. Salah satu cara paling penting dan mudah dalam uji keabsahan hasil penelitian adalah dengan melakukan triangulasi sumber, metode, peneliti, dan teori [8]. Analisis data dalam penelitian ini dilakukan berdasarkan analisis interaktif. Seperti ilustrasi pada Gambar 2, analisis tersebut terdiri dari tiga komponen analisis yang saling berinteraksi, yaitu: reduksi data, display data dan pengambilan keputusan dan verifikasi. Apabila kesimpulan dirasa kurang mantap, maka peneliti kembali ke lapangan untuk mengumpulkan data dan seterusnya 
sampai diperoleh data yang betul-betul mantap, sehingga merupakan suatu siklus.

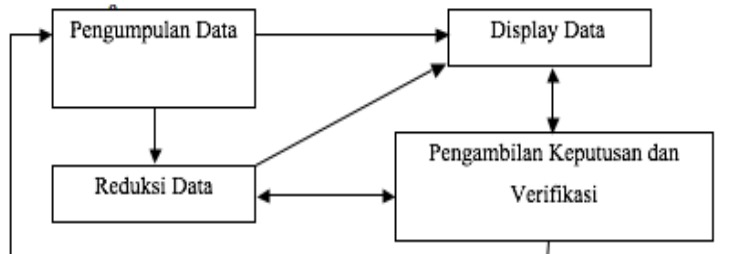

Gambar 2. Tahap-tahap Analisis Data [9]

Dengan demikian ada berbagai cara untuk menganalisis data, tetapi secara garis besarnya dengan langkah-langkah sebagai berikut: (a) reduksi data, (b) display data (c) pengambilan kesimpulan dan verifikasi.

a. Reduksi Data: Jika dalam penelitian kualitatif terdapat data yang bersifat kuantitatif yaitu dalam bentuk angka-angka, maka sebaiknya angka-angka itu jangan dipisahkan dari katakatanya secara kontekstual, sehingga tidak mengurangi maknanya. Data yang didapat di lapangan langsung diketik atau ditulis dengan rapi, terinci serta sistematis setiap selesai mengumpulkan data. Data-data yang terkumpul semakin bertambah biasanya mencapai ratusan bahkan ribuan lembar. Oleh sebab itu laporan itu harus dianalisis sejak dimulainya penelitian. Laporan-laporan itu perlu direduksi, yaitu dengan memilih hal-hal pokok yang sesuai dengan fokus penelitian, kemudian dicari temanya. Data-data yang telah direduksi memberikan gambaran yang lebih tajam tentang hasil pengamatan dan mempermudah peneliti untuk mencarinya jika sewaktu-waktu diperlukan. Reduksi dapat pula membantu dalam memberikan kode-kode pada aspek-aspek tertentu.

b. Display Data: Data yang semakin bertumpuktumpuk itu kurang dapat memberikan gambaran secara menyeluruh. Oleh sebab itu diperlukan display data. Display data ialah menyajikan data dalam bentuk matrik, network, chart, atau grafik, dan sebagainya. Dengan demikian, peneliti dapat menguasai data dan tidak terbenam dengan setumpuk data.

c. Pengambilan Keputusan dan Verifikasi: Sejak semula peneliti berusaha mencari makna dari data yang diperolehnya. Untuk maksud itu, ia berusaha mencari pola, model, tema, hubungan, persamaan, hal-hal yang sering muncul, hipotesis, dan sebagainya. Jadi dari data yang didapatnya itu ia mencoba mengambil kesimpulan. Mula-mula kesimpulan itu kabur, tetapi lama-kelamaan semakin jelas karena data yang diperoleh semakin banyak dan mendukung. Verifikasi dapat dilakukan dengan singkat yaitu dengan cara mengumpulkan data baru.

\section{METODOLOGI PENELITIAN}

Pada bagian ini penulis ingin menunjukkani metodologi penelitian yang digunakan untuk kesiapan implementasi BCMS berbasis ISO 22301:2012 untuk PT XYZ.

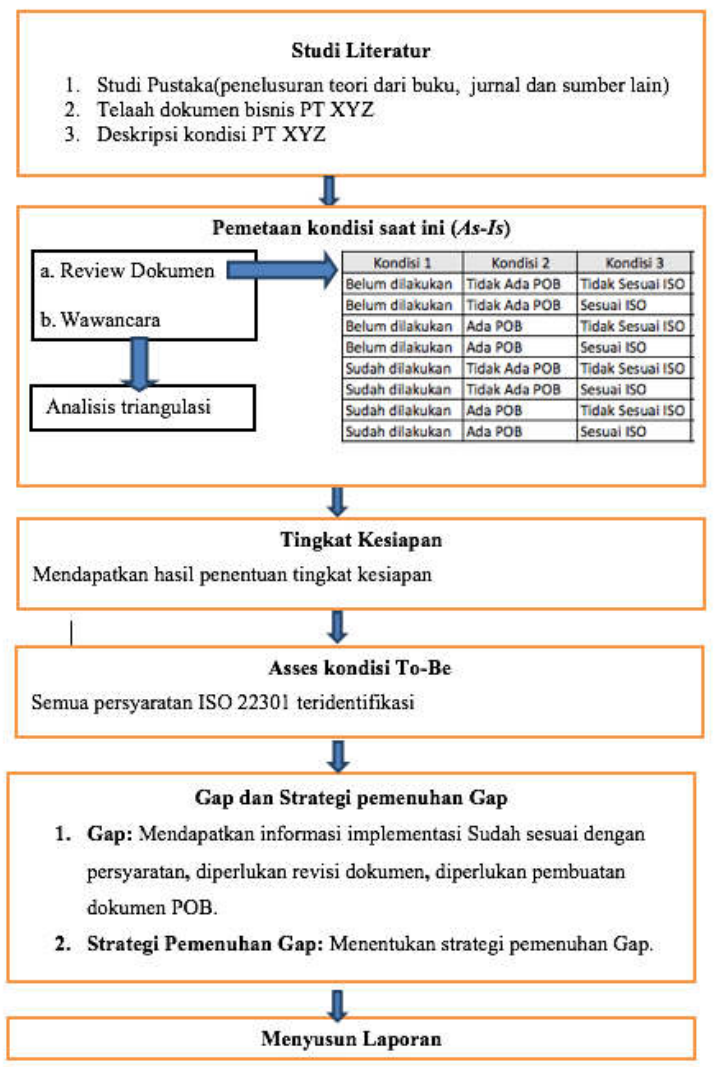

Gambar 3. Metodologi Penelitian

Studi literatur yang dilakukan dalam penelitian ini adalah pembelajaran literatur terkait dengan permasalahan yang ada seperti pembelajaran mengenai Bisnis Continuity Management, sejarah perusahaan, proses bisnis yang ada pada PT XYZ, prosess pembuatan POB dan standar ISO 22301:2012. Review dokumen dilakukan dengan cara mereview dokumen terkait dengan proses bisnis yang ada di PT XYZ. Pengumpulan data melalui wawancara kepada responden diidentifikasi dengan pendekatan identifikasi yang mengacu pada diagram RACI. Kemudian penentuan tingkat kesiapan PT XYZ terhadap implementasi ISO 22301. Tingkat kesiapan tersebut diperoleh dari perbandingan hasil cheklist review dokumen, pengamatan observasi dilapangan dan hasil wawancara. Kemudian diidentifikasi gap dengan membandingkan hasil dari assesmen as-is dengan hasil dari assesmen to-be sehingga dapat ditentukan strategi pemenuhan gap dan menyusun laporan. 


\section{HASIL DAN PEMBAHASAN}

Studi literatur yang dilakukan dalam penelitian ini adalah pembelajaran literatur terkait dengan permasalahan yang ada seperti pembelajaran mengenai Bisnis Continuity Management, sejarah perusahaan, proses bisnis yang ada pada PT XYZ, prosess pembuatan POB dan standar ISO 22301:2012.

Pemetaan kondisi as-is dimulai dengan mengidentifikasi RACI. Pengumpulan data melalui prosess wawancara, data responden diidentifikasi dengan pendekatan identifikasi responden yang mengacu pada diagram RACI, maka sampling atau identifikasi responden diarahkan pada peran-peran yang terkait langsung dan representatif pada prosess perencanaan. Dari 13 responden yang sudah ditentukan dipilih responden yang mempunyai wewenang sebagai top management sehingga terpilihlah 5 responden yang diwawancarai. Hal ini sesuai dengan clausul 5.1 Leadership and Commitment ISO 22301 dijelaskan bahwa orang yang ditunjuk sebagai top manajemen harus mendemonstrasikan kepemimpinan dan komitmen pada organisasi yang mengimplementasikan BCMS.

Pelaksanaan review dokumen dilakukan dengan menggunakan tools berupa cheklist. Cheklist tersebut disesuaikan dengan persyaratan yang diminta oleh ISO 22301 dan ditambah kontrol untuk dapat mengidentifikasi kondisi eksisting prosess, dokumentasi dan aktivitas di PT XYZ. Kondisi sesuai dengan Gambar 3. Dalam cheklist terdapat 106 kontrol yang dilakukan mapping.

\begin{tabular}{|c|c|c|c|c|c|c|c|}
\hline Kondisi 1 & Kondisi 2 & Kondisi 3 & & inar & & Nilai & Action \\
\hline $\begin{array}{l}\text { Belum } \\
\text { dilakukan }\end{array}$ & \begin{tabular}{|l|} 
Tidak \\
Ada POB
\end{tabular} & $\begin{array}{l}\text { Tidak Sesuai } \\
\text { Iso }\end{array}$ & 0 & 0 & 0 & 0 & $\begin{array}{l}\text { Membuat POB } \\
\text { dan } \\
\text { Implementasi } \\
\text { POB }\end{array}$ \\
\hline $\begin{array}{l}\text { Belum } \\
\text { dilakukan }\end{array}$ & \begin{tabular}{|l|} 
Tidak \\
Ada POB
\end{tabular} & Sesuai ISO & 0 & 0 & 1 & 1 & N/A \\
\hline $\begin{array}{l}\text { Belum } \\
\text { dilakukan }\end{array}$ & Ada POB & $\begin{array}{l}\text { Tidak Sesuai } \\
\text { ISO }\end{array}$ & 0 & 1 & 0 & 2 & $\begin{array}{l}\text { Merevisi POB } \\
\text { dan } \\
\text { Implementasi } \\
\text { POB }\end{array}$ \\
\hline $\begin{array}{l}\text { Belum } \\
\text { dilakukan }\end{array}$ & Ada POB & Sesuai ISO & 0 & 1 & 1 & 3 & $\begin{array}{l}\text { Implementasi } \\
\text { POB }\end{array}$ \\
\hline $\begin{array}{l}\text { Sudah } \\
\text { dilakukan }\end{array}$ & \begin{tabular}{|l|} 
Tidak \\
Ada POB \\
\end{tabular} & $\begin{array}{l}\text { Tidak Sesuai } \\
\text { ISO }\end{array}$ & 1 & 0 & 0 & 4 & Membuat POB \\
\hline $\begin{array}{l}\text { Sudah } \\
\text { dilakukan }\end{array}$ & \begin{tabular}{|l|} 
Tidak \\
Ada POB \\
\end{tabular} & Sesuai ISO & 1 & 0 & 1 & 5 & Membuat $\mathrm{POB}$ \\
\hline $\begin{array}{l}\text { Sudah } \\
\text { dilakukan }\end{array}$ & Ada POB & $\begin{array}{l}\text { Tidak Sesuai } \\
\text { ISO }\end{array}$ & 1 & 1 & 0 & 6 & Merevisi POB \\
\hline $\begin{array}{l}\text { Sudah } \\
\text { dilakukan }\end{array}$ & Ada POB & Sesuai ISO & 1 & 1 & 1 & 7 & Teridentifikasi \\
\hline
\end{tabular}

Gambar 3. Kontrol pada cheklist assesment

Penjelasan maksud dari Gambar 3 sebagai berikut. Ketika peneliti melakukan assessment pada klausul 4.1.c pada ISO 22301 yang mempersyaratkan bahwa organisasi mendefiniskan risk appetite (risiko terhadap asset yang terkena dampak pada implementasi ISO 22301), assesment pada kondisi 1, jika perusahaan sudah melakukan aktivitas ini diupdate pada kolom binary $1 / 0$, kemudian lanjut pada kondisi 2, jika apakah perusahaan sudah membuat $\mathrm{POB} /$ terdokumentasi terkait aktivitas ini? Jika ada makan diupdate pada kolom binary 1/0, kemudian lanjut pada kondisi 3, jika apakah aktivitas/prosess, POB/dokumentasi sudah sesuai dengan ISO 22301? Jika sesuai maka update di kolom binary 1/0. Dari kolom binari tersebut kemudian dikonversi menjadi desimal. Misal kondisi 1: 1 kondisi 2: 1 kondisi 3: 0 maka konversi desimalnya 110 adalah 6 .

Wawancara terdiri dari 24 pertanyaan open question untuk mengetahui profil dan sejarah perusahaan, komitmen dari managemen terhadap implementasi dari ISO 22301, tingkat kesiapan implementasi ISO 22301 dari sudut pandang managemen dan strategi pemenuhan gap yang ada terhadap implementasi ISO 22301.

Analisa triangulasi dilakukan berdasarkan data hasil penelitian yang sudah dilakukan baik tahapan review dokumen, observasi lapangan dan wawancara ada salah satu konsen yang diangkat oleh penulis untuk mengetahui tingkat kesiapan yaitu: peneliti ketengahkan hasil wawancara dengan VP PMO yang menjelaskan sebagai berikut: Penuturan dari VP CMS:

"Ukurannya bahwa suatu PT belum mengimplementasikan BCMS, juga belum ada POB yaitu Top Management menginstruksikan kepada jajaranya untuk mengimplementasika BCMS. PT XYZ sudah siap untuk implementasi BCMS yang mengacu pada ISO 22301:2012. Alasannya adalah karena sudah mempersiapkan 2 tahun implementasinya dan tuntutan dari customer untuk implementasi BCMS. Adapun bagaimana mengukur tingkat kesiapan suatu PT untuk implementasi BCMS yang mengacu pada ISO 22301:2012 yaitu dukungan Top Management, dilaksanakan awareness kepada seluruh karyawan, Internal Audit, testing pelaksanaan BCP" (Wawancara dengan VP CMS tanggal 25 Juni 2016)”.

\section{Penjelasan dari Human Capital pada peneliti sebagai berikut:}

“Apa saja ukurannya bahwa suatu PT sudah mengimplementasikan BCMS ini dan telah memiliki $P O B$, maka jawaban saya yaitu dukungan Top Management, ukuranya bahwa secara operasional sudah menerapkan clausul-clausul yang ada di BCMS dan dalam penerapannya sudah mempunyai standar operasional Baku dan diterapkan secara konsisten dengan dilakukan audit secara berkala (Wawancara dengan Human Capital tanggal 28 Juni 2016)".

Berdasarkan hasil rekapitulasi review dokumen dapat dilihat distribusi nilai kesiapan seperti pada Gambar 4, distribusi nilai kesiapan, bahwa masih terdapat banyak kontrol pada ISO 22301 yang belum diimplementasikan oleh PT XYZ yaitu dilihat dari frekuensi nilai 0 sebanyak 15 kontrol atau $14.2 \%$ dari seluruh kontrol klausul yang dipersyaratkan oleh ISO 22301, yang artinya PT XYZ tidak comply $14.2 \%$ dari klausul ISO 22301 , harus dikejar dengan membuat prosedur baru dan implementasi. 


\begin{tabular}{|c|c|c|c|c|c|c|c|c|c|}
\hline & 0 & 1 & 2 & 3 & 4 & 5 & 6 & 7 & $\begin{array}{c}\text { Total } \\
\text { Control }\end{array}$ \\
\hline Plan & 10 & 0 & 6 & 0 & 12 & 9 & 2 & 17 & 56 \\
\hline Do & 5 & 0 & 2 & 0 & 0 & 3 & 8 & 11 & 29 \\
\hline Chek & 0 & 0 & 1 & 3 & 0 & 1 & 1 & 12 & 18 \\
\hline Act & 0 & 0 & 0 & 0 & 1 & 0 & 0 & 2 & 3 \\
\hline & 15 & 0 & 9 & 3 & 13 & 13 & 11 & 42 & 106 \\
\hline
\end{tabular}

Gambar 4. Distribusi nilai kesiapan

Dapat dilihat untuk kontrol yang teridentifikasi atau mempunyai nilai 7 adalah $39.6 \%$ dan kontrol yang diantara comply dan tidak adalah $46.2 \%$, yang artinya $60.4 \%$ kontrol yang harus dibenahi oleh PT XYZ baik dari segi implementasi, pembuatan dokumen baru ataupun revisi dokumen yang sudah ada.

Tingkat Kesiapan: Meresume dari penjelasan diatas hasil wawancara dari 2 sumber dan hasil cheklist assesment bahwa top managemen mendukung implementasi ISO 22301 yang dilakukan oleh PT XYZ, dengan melakukan continual improvement terhadap proses-proses yang belum memenuhi persyaratan ISO 22301. PT XYZ siap melakukan implmentasi ISO 22301 dengan catatan dapat melakukan perbaikanperbaikan proses, implementasi dan dokumentasi sesuai persyaran ISO 22301.

Gap: Sesuai ilustrasi dari gambar 5 Distribusi As Is dan Gap, bahwa ada 60.4\% kontrol yang harus diperbaiki oleh PT XYZ baik dari segi implementasi, pembuatan $\mathrm{POB}$ dan revisi $\mathrm{POB}$

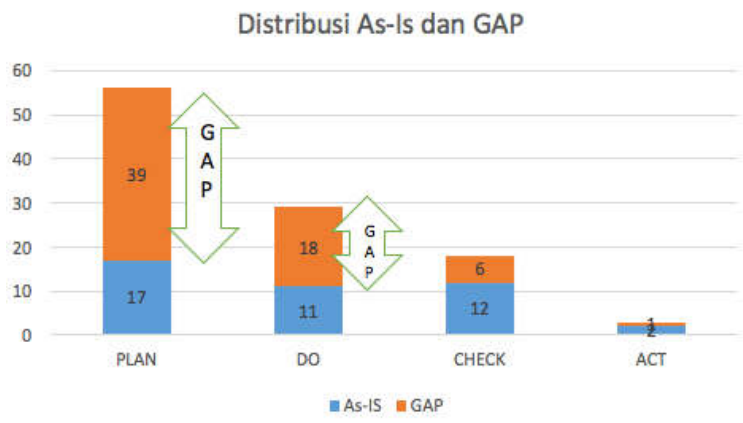

Gambar 5. PDCA Distribusi As Is dan Gap

Dapat dilihat distribusi PDCA dari klausul yang sesuai (teridentifikasi/comply) dengan klausul yang tidak comply, baik yang benar-benar tidak comply maupun comply dengan catatan. diperoleh list kebutuhan dokumen yang harus ada untuk implementasi ISO 22301. Dapat peneliti jelaskan untuk Plan terdapat 39 kontrol yang harus dibenahi baik itu revisi dokumen yang sudah ada, pembuatan dokumen baru atau implementasi dilapangan. Begitupun untuk Do, Chek dan Act nya.

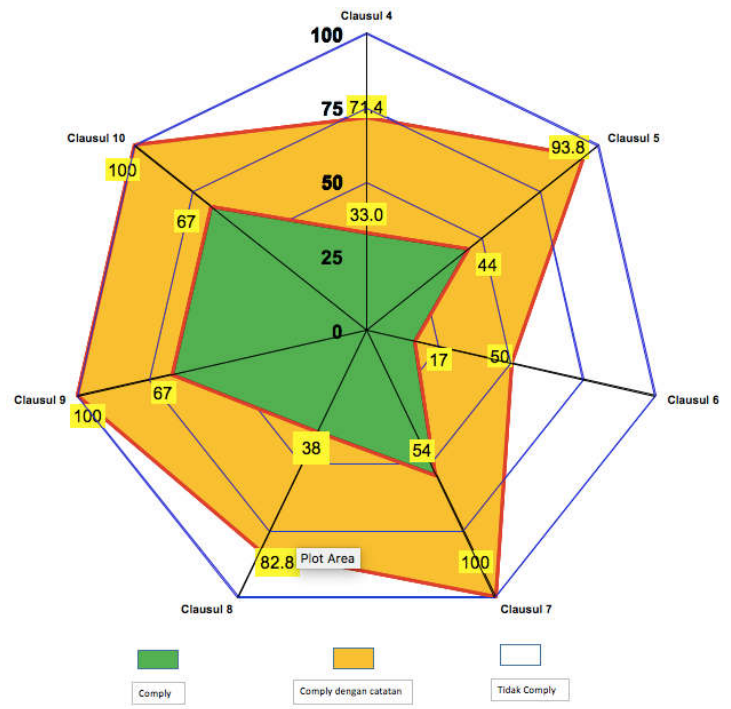

Gambar 6. Distribusi kesesuaian pada setiap klausul ISO 22301

Pada Gambar 6 dapat dilihat distribusi \% kesesuaian klausul terhadap implementasi kondisi saat ini dari PT XYZ. Dapat dilihat area yang berwarna putih klausul 4 (contect of the organization), klausul 6 (planning) dan klausul 8 (operation) mempunyai gap ketidak sesuai paling banyak (nilai 0), yang artinya dokumen dan implementasinya masih harus diidentifikasi dan diterapkan. Sedangkan area yang berwarna orange adalah area dimana sudah ada dokumen/ implementasi sudah dilaksanakan tetapi masih perlu direvisi baik itu dokumentasi maupun implementasinya. Sedangkan yang area warna hijau adalah area yang sudah teridentifikasi/comply, dapat dilihat klausul 9 (performance evaluation) dan klausul 10 (improvement) memiliki kesesuaian paling tinggi karena dokumentasi dan implementasi sama dengan ISO yang lain yang dimiliki oleh PT XYZ.

Dari 106 kontrol yang diperiksa, penulis mengidentifikasi 16 dokumen POB yang dibutuhkan. Selain POB ada dokumen berupa record/rekaman yang dibutuhkan, tetapi pada kesempatan ini penulis mengidentifikasi dokumen berupa POB. Dari 16 dokumen tersebut penulis membuat resume terhadap action tindak lanjutnya. Kutipan dari Direktur SDO:

"Dukungan Top Management, Pada dasarnya POB untuk BCMS ada banyak, saya bisa menunjukkan POB apa saja yang kita punya, tetapi $P O B$ ini tidak sepenuhnya mengatur mengenai BCMS tetapi juga beririsan dengan ISO 9001 dan ISO 27001 yang sudah disertifikasi. Dokumen yang saya tunjukkan adalah Dokumen Bisnis impact analisis (BIA), Risk assessment (RA), dokumen strategi BCM. Untuk prosedur bisa ditanyakan kepada VP lain.” 
Merujuk pada hasil assesmen dokumen dan hasil wawancara seperti kutipan direktur SDO diatas, analisa penulis bahwa tidak semua dokumen yang sudah diidentifikasi dibuat atau direvisi disampaikan semua dalam penelitian ini. Tetapi merujuk pada beberapa mandatory dokumen yang belum dibuat dan hasil wawancara dengan Top manajemen PT XYZ menyetujui untuk dibuatkan dokumen antara lain:

1. Policy BCM ( buat baru )

2. Risk assessment ( revisi )

3. Prosedur BCP Strategy ( buat baru )

4. Prosedur BIA ( revisi )

Untuk dokumen-dokumen yang lain dibuatkan rencana implementasi yang realible. Rencana pemenuhan Gap: Dalam penjelasan sebelumnya dijelaskan bahwa top manajemen menyetujui untuk dibuatkan dokumen yang mempunyai kritikalitas tinggi. Untuk itu dibuat rencana pemenuhan implementasi ISO 22301 di PT XYZ yaitu :

1. Membuat strategi jadwal implementasi: Jadwal implementasi yang dibuat terdiri dari aktivitas yang sudah dilakukan dalam penelitian ini dan aktifitas yang dilakukan oleh PT XYZ itu sendiri. Penulis memberikan usulan aktifitas yang dilakukan PT XYZ sesuai informasi yang ada pada dokumen ISO 22301.

2. Membuat POB yang sudah diidentifikasi sebelumnya: menyusun prosedur operasional baku yang sesuai dengan persyaratan implementasi BCM.

\section{KESIMPULAN}

Bada bagian ini akan disampaikan kesimpulan dan saran terhadap penelitian yang telah dilakukan.

\section{A. Kesimpulan}

Bahwa top managemen mendukung implementasi ISO 22301 yang dilakukan oleh PT

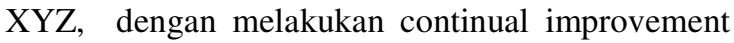
terhadap proses-proses yang belum memenuhi persyaratan ISO 22301. PT XYZ siap melakukan implmentasi ISO 22301 dengan catatan dapat melakukan perbaikan-perbaikan proses [10], implementasi dan dokumentasi sesuai persyaratan ISO 22301

\section{B. Saran}

Perlu langkah-langkah strategis oleh peneliti lain terutama untuk menentukan atau melakukan mapping antara kontrol pada standart khususnya untuk standar ISO 22301 dengan kondisi implementasi pada suatu perusahaan. Karena klausul-klausul yang ada pada standar ISO adalah general sehingga perlu suatu metode yang lebih fokus mengerucut terhadap makna dari klausulklausul yang ada pada standar ISO.

\section{DAFTAR PUSTAKA}

[1]. Boehmer, W., 2009. Survivabilityand Business Continuity Management System According BS 25999. IEEE. Hochschlulstr, Germany: IEEE.

[2]. BSI, 2010. Bisnis Continuity Management System: Requirement with Guidance For use, American Nasional Standart, ASIS International.

[3]. International Standart, 2012. International Organization for Standardization (ISO) 22301:2012 Business Continuity Management System. Case Postale, Geneva.

[4]. Avaluation Consulting and BSI Management System America., 2010. How to Deploy BS 25999 2nd Edition.

[5]. Andrew Hiles, 2007. The Definitive Handbook of Business Continuity Management Second Edition, England, Kingswell International Limited

[6]. Moleong, Lexy J., 2012. Metodologi Penelitian Kualitatif, Bandung: PT. Remaja Rosdakarya.

[7]. Miles, Mattew B. dan A. Michael Haberman, 2010, Analisis Data Kualitatif, Jakarta: UI Press.

[8]. Danim, Sudarwan, 2012. Menjadi Peneliti Kualitatif. Bandung: CV Pustaka Setia

[9]. Bungin, Burhan, 2017. Penelitian Kualitatif, Jakarta, Kencana.

[10]. Anang Hidayat, 2007. Strategi Six Sigma, Peta Pengembangan Kualitas dan Kinerja Bisnis, Jakarta, PT. Elex Media Komputindo. 